\title{
Jakarta Bay reclamation policy: an analysis of political ecology
}

\author{
Elok Faiqotul Mutia ${ }^{1}$ and Donna Asteria ${ }^{2, *}$ \\ ${ }^{1}$ School of Environmental Science, Universitas Indonesia, Salemba, Indonesia \\ ${ }^{2}$ Communication Department, Faculty of Social and Political Science, Universitas \\ Indonesia, Depok, Indonesia
}

\begin{abstract}
The Jakarta Bay reclamation policy is an issue that is currently a public debate. This debate is strengthened by environmental issues, the marginalization of certain groups, the regulation of authority and also corruption in the Jakarta Bay Reclamation project. Some central and provincial government institutions take different stances on the issue. The first objective of this research is to analyse environmental policy in reclamation of Jakarta Bay with the approach of political ecology. This research uses a qualitative approach. The data were obtained from in-depth interviews with stakeholders involved in the policy making of the Jakarta Bay reclamation environment and the literature study. This study concludes that the Jakarta Bay reclamation policy creates a conflict between the central and provincial governments. This is due to the overlapping regulation of Jakarta Bay reclamation authority as well as differences in attitude and interests among stakeholders. In the approach of political ecology, the Jakarta Bay reclamation policy has failed to accommodate the three interests, are social, economic and environmental interests. The conflicts that occur also cause an omission that not only harms the economy, but worsens the social and economic impact.
\end{abstract}

\section{Introduction}

\subsection{Background}

The Jakarta Bay reclamation policy was initiated from the General Spatial Plan of DKI Jakarta from 1985 to 2005 which stated that small-scale reclamation in Penjaringan, Pademangan, Ancol, and Pluit is required to meet the growing demand for the population of Jakarta. in 1994 issued Presidential Decree. 17 of 1994 which states Pantura Jakarta as a Mainstay Area. in 1995 issued Presidential Decree no. 52 of 1995 on the Implementation of North Jakarta Beach Reclamation, which was followed up by the Jakarta Provincial Regulation no. 6 of 1999 on Spatial Planning of DKI Jakarta. Reclamation objectives are increasing for international trade and services, housing for the upper middle class and tourist ports.

\footnotetext{
*Corresponding author: donna@ui.ac.id
} 
The Jakarta Bay reclamation policy is now a policy that raises debates among stakeholders. This debate is strengthened by environmental issues, the marginalization of certain groups, the regulation of authority and also corruption in the Jakarta Bay Reclamation project. The reclamation of Jakarta Bay is considered to threaten the ecosystem in the coastal area of Jakarta Bay. Mangrove forest in Jakarta Bay, which have an important role, is one of the threaten by reclamation project [1]. Same as, the mangrove forest, the water quality will be threatened by Jakarta Bay reclamation. It will affect not only the environment, but also economic loss for fisherman [2]. In addition to the regulatory process for the implementation of the Jakarta Bay reclamation policy, there are corruption issues involving investors and members of the DPRD. This then raises the reaction from stakeholders who feel competent and interested in the project.

Minister of Marine Affairs and Fisheries, Susi Pudjiastuti, stated that the reclamation developers in the Jakarta Bay must complete the permits of the Ministry of Marine Affairs and Fisheries (KKP). Prior to the permit, the project must be stopped. Not only the KKP, Minister of Marine Affairs Coordinator for the period of 2015-2016, Rizal Ramli, also took a stand by cancelling the development of $\mathrm{G}$ Island. The decision was taken by considering the violations committed by developers such as the development of the island which is done on the PLN power lines as well as the act of shutting down and disrupting the access road of fishermen. In addition, the technical development of $\mathrm{G}$ island is considered to potentially damage the marine biota. However, his stance to the Jakarta Bay reclamation changed when the position of the minister was replaced by Luhut Panjaitan in July 2016. In his leadership, he decided that the Jakarta Bay reclamation would be continued. Ministry of Environment and Forestry (KLHK) also took a position in this issue. KLHK took their steps on the basis of their authority over the environment which is threatened by the Jakarta Bay reclamation.

DKI Jakarta Provincial Government took their stance based on Presidential Decree (Presidential Decree) Number 52 Year 1995 and Presidential Regulation (Perpres) Number 122 Year 2012 in the debate of Jakarta Bay reclamation. Both regulations give the authority to the provincial government for the implementation of the Jakarta Bay reclamation. DKI Jakarta Provincial Government affirmed that the Jakarta Bay reclamation could no longer be stopped because some islands such as C and D have been formed. The Jakarta Bay reclamation is considered not only a solution to the land limitations and flood management, but also to the fishermen's socio-economic interests. This is manifested into strategic environmental assessment (KLHS) a spatial plan for Jakarta north coast strategic area which has been validated by the Ministry of Environment and Forestry. The government institutions different stances indicate the different interests in the Jakarta Bay reclamation. To date, the Jakarta Bay reclamation still has no clear decision, be it to cancel or to continue.

\subsection{Conflict}

Conflict happen when two or more subject have difference interest with the some object [3][4]. It also can happen because subjects have difference access and inequalities to resources [5]. In Jakarta Bay Reclamation, this happened with the conflict over the rejection of the Jakarta Bay reclamation which considered that there were no interests of the coastal communities accommodated, especially the people who relied on the Jakarta Bay as the main source of income [6]. According to Mitchell et al. (2003), the roots of arising conflict include four aspects, namely: differences in knowledge and understanding, differences in values, differences in interests, as well as personal issues or historical background [7]. In this research, conflict can be arise because of management of resources. Resource conflicts occur often due to differences in perception or interpretation of the resource is manifested in their attitude [8]. Conflict over natural resources can occur at various levels, from local, 
regional, to global. Conflicts can also occur between these levels. Conflicts occurring primarily in local contexts can extend the traditional, regional and global levels due to their specific legal relevance [9][10]. In Indonesia, resources conflict that happened between central and provincial government because of several things, such as decentralization [11], overlapping of regulation [12], and conflict of interest in management of resources [13]. In the global level, resource conflicts caused by gaps of demand and supply [14], which makes resources value increased and attract many actors to be involved. Not only gaps demand and supply, inequality access to resources can also lead to conflict [15]. In this research, resource conflicts occur due to high value resources and different perceptions and interests of stakeholders at Jakarta Bay Reclamation.

\subsection{Political ecology}

The political ecology approach is an interdisciplinary approach to analysing environmental conflicts about the social relationships of actors, who are often dubbed "stakeholders", in conflict [16]. Martinez-Alier (2002) defines political ecology as the study of the distribution of ecological conflicts, such as conflicts over access, control, natural resources, livelihoods, and including environmental damage costs [17]. Methodologically, political ecology deals with the theory of social practice that understands society through the practice of resource users, or the actors, and the social relations that accompany the process of production in line with their existence in time and space, or certain spatiality, and in relationships social welfare [18]. Although the political ecology approach has been widely used to analyse human and environmental relations, there is a growing political ecology focus on what affects human action itself. Two influential theoretical models that have become the theoretical lenses in political ecology derive from poststructuralism and Marxism. Despite its unique theoretical foundation, the resulting conceptual approach becomes a highly influential lens in human learning, nature, and power.

Political ecology approach also began to be used as a way of looking at the problems that exist in Indonesia. Arifin (2012) in his research entitled "political ecology: environmentally friendly as justification" gives one conclusion that environmentally friendly discourse is used as a tool by certain groups to influence the behavioural patterns of society including behaviour in the consumption of certain goods [19]. Arifin's research focuses on political ecology as an analysis of discourse formation. Research conducted Tarigan (2016) using a political ecological approach to analyze agricultural transformation and water crisis that occurred in Bali. This study shows that the water crisis is causing conflict between stakeholders and marginalizing agriculture. This is due to the politics of tourism-oriented development that brings a widespread impact on the utilization of water resources [20]. Political ecology approach used by Tarigan is to understand the relationship between actors in the utilization of water resources. Teak (2013) uses a political ecological approach as a just paradigm of natural resource governance. According to Jati, natural resource governance should put people and nature on the same level. Community involvement is also necessary in the management of natural resources [21]. This study uses the same approach with the previously mentioned research approach. However, in this research the political ecology approach is used as a perspective to describe environmental policy in reclamation of Jakarta Bay.

\section{Methodology research}

The purpose of this study is to analyse the policy of Jakarta Bay reclamation with the approach of political ecology. This study will analyse the policy of each institution that related to Jakarta Bay Reclamation. It's include the statement of stakeholder in in-depth 
interview. Political ecology will used to approach to describe the relation of stakeholder ini Jakarta Bay Reclamation. This research uses a qualitative approach by conducting in-depth interviews to stakeholders. The stakeholder consists of the central government and the provincial governments with some criteria that show in Table 1. Selected ministries and agencies based on their involvement and authority in the reclamation of the bay of Jakarta. In addition, selected ministries and agencies are those involved in policy debates. Questions in in-depth interviews are open so that researchers can explore questions according to stakeholder responses. Exploration in literature studies has been done for adding, comparation and clarifying information.

Table 1. Criteria of Stakeholder.

\begin{tabular}{|c|c|l|l|}
\hline No. & $\begin{array}{c}\text { Code of } \\
\text { Informant }\end{array}$ & \multicolumn{1}{c|}{ Institution } & \multicolumn{1}{c|}{ Criteria } \\
\hline 1 & A001 & Ministry of Environment and Forestry & $\begin{array}{l}\text { Having knowledge of Jakarta } \\
\text { Bay reclamation and being or } \\
\text { having been involved in the }\end{array}$ \\
\hline 2 & A002 & Ministry of Marine Affairs and Fisheries & $\begin{array}{l}\text { Jakarta Bay reclamation } \\
\text { policy process }\end{array}$ \\
\hline 3 & A003 & Coordinating Ministry for Maritime Affairs & \\
\cline { 1 - 3 } 4 & B001 & $\begin{array}{l}\text { Regional Development Planning Agency } \\
\text { DKI Jakarta }\end{array}$ & \\
\hline 5 & B002 & Environmental Agency DKI Jakarta & \\
\cline { 1 - 3 } 6 & B003 & $\begin{array}{l}\text { Office of Public Works - Human Settlements } \\
\text { and Spatial Planning DKI Jakarta }\end{array}$ \\
\hline
\end{tabular}

The result of the interview will write a word into a verbatim transcript which will then be analyzed using Nvivo. Transcripts will be categorized based on certain variables such as knowledge, interests, authority and conflict. The results of the analysis are validated by comparing discourse studies and policy analysis.

\section{Result and discussion}

The results of in-depth interviews and literature studies indicate that there are different views among stakeholders regarding Jakarta's reclamation policy. This difference in view is due to two things, differences in authority and different attitudes and interests.

\subsection{Authority regulation}

To date, there are 3 regulations that are used as the basis for the authority of Jakarta Bay reclamation. The regulation gives authority to 3 different stakeholders. First, the authority of the Provincial Government of DKI Jakarta. Article 4 of Presidential Decree 52 of 1995 on North Coast Reclamation Jakarta to date still remains the basis of the Provincial Government of DKI Jakarta that the authority and responsibility of the Pantura Reclamation reside in the Governor of DKI Jakarta. But there is a debate because in article 3 verse 1, the notion of reclamation is not a new island, the reclamation covers the waters of Jakarta which is measured from the north coastline of Jakarta perpendicularly towards the sea until the line connecting the outermost point shows the depth of 8 meters. It then reap the debate whether the current reclamation is in accordance with the Presidential Decree. However, the Presidential Regulation No. 54 of 2008 on Spatial Planning of Jakarta, Bogor, Depok, Tangerang, Bekasi, Puncak, Cianjur regulates reclamation should be done by forming the island, where there are lateral canals \pm 200-300 meters between land with reclaimed island, depending on the zonation. In this presidential regulation, there is no article which states the change of authority. 
Second, the authority of the Ministry of Marine Affairs and Fisheries. Presidential Regulation No. 122/2012 on Reclamation in Coastal Areas and Small Islands Article 16 paragraph 2, said the Minister grants location permits and permits for the implementation of reclamation in certain National Strategic Areas, reclamation activities across provinces, and reclamation activities at fishery ports managed by Government, while Presidential Regulation No. 54 of 2008 establishes Pantura as part of the National Strategic Area. So in this case the Minister also has the authority to grant permission. However, in article 2, paragraph 2a, there is an exclusion for reclamation in the Work Area (DLKr) and Regional Environment Interests (DLKp) of the main ports and harbor collectors as well as in the territorial waters of special terminals. With this article and the release of a letter from the Minister of Transportation, the Ministry of Marine Affairs and Fisheries withdrew from the authority of the Jakarta Bay reclamation.

Third, the authority of the Ministry of Transportation. Government Regulation of the Republic of Indonesia Number 5 Year 2010 On navigating derived from Minister of Transportation Regulation no. 136 of 2015 Second Amendment to Regulation of the Minister of Transportation No. PM 52 of 2011 on Dredging and Reclamation states that reclamation in the Working Zone (DLKr) and Regional Environment Interests (DLKp) of the main port and gathering port as well as in the territorial waters of special terminals shall obtain permission from the Minister of Transportation. The reclamation of Jakarta Bay enters DLKr and DLKp Sunda Kelapa and Tanjung Priuk.

This overlapping regulation of authority makes conflicts among stakeholders who feel that the reclamation of the Bay of Jakarta is the authority of their institution. The settlement of this matter of authority is then resolved by forming a joint committee consisting of several stakeholders, which is chaired by the Coordinating Ministry for the Ministry of Marine Affairs, and comprising the Ministry of Marine Affairs and Fisheries, Ministry of Environment and the Provincial Government of DKI Jakarta. In the Committee it is stipulated that the authority of the Jakarta Bay reclamation is in the Provincial Government of DKI Jakarta

\subsection{Differences in attitudes and interests}

The continuation of the reclamation of the Jakarta Bay is still unclear. Whereas on the other hand, there are 2 islands that have been formed even already have a number of buildings. The policy on the continuation of the reclamation of the Bay of Jakarta is based on the importance of what the stakeholders are interested in and wants to achieve. The Jakarta Bay reclamation policy was initially based on the need for land for settlements and the desire to create waterfront city. In 1999, the reclamation objectives increased for international trade and services, housing for the upper middle class and tourist ports. However, environmental problems that occurred in Jakarta made the government prioritize the handling of the environment. The condition of the waters of Jakarta Bay has now exceeded the quality standard and polluted. The results of monitoring conducted by the Environmental Agency, 11 sample points expressed exceeded the quality standard. This shows that the ecosystem in the waters of Jakarta Bay is being threatened, therefore, it needs a policy that is able to solve environmental problems in Jakarta Bay.

The Jakarta Bay reclamation policy is judged by some stakeholders to still not accommodate environmental and social interests and is still dominated by economic interests. The results of the field visits conducted by the Ministry of Environment, the Ministry of Marine Affairs and Fisheries, the Ministry of Coordinating Ministry of Marine Affairs and the Provincial Government of DKI Jakarta in May 2016. In the visit, found several violations, including permission violations and considered not to improve the quality of the environment, it will exceed carrying capacity and environmental capacity in 
the long term. In addition, the Ministry of Marine Affairs and Fisheries assessed there were violations in the technical aspects and neglect of the interests of the fishermen community. Although a temporary suspension or moratorium was suspended, the final decision of the joint committee decided that the reclamation of the Jakarta Bay was still in place. Although this decision has been conveyed through the Coordinating Ministry for the Ministry of Environment, Ministry of Environment and Forestry, stressed the need for regulation to oversee the policy of Jakarta Bay reclamation. This is necessary because until now the reclamation of Jakarta Bay is dominated by the investor's economic interest, so the position of the country is weak. It's stronger with the statement of two of informant that said the government need stronger rules and position as a controller of the Jakarta Bay Reclamation, and same as in the project of NCICD [22]. The same thing is also conveyed by the Ministry of Marine Affairs and Fisheries which is still on the same view and attitude, namely Jakarta Bay reclamation policy should be cancelled.

Table 2. Results of Jakarta Bay Estuary Water Monitoring.

\begin{tabular}{|c|l|c|c|}
\hline No. & \multicolumn{1}{|c|}{ Sample Location } & $\begin{array}{c}\text { Fulfillment Quality } \\
\text { Standards }\end{array}$ & Pollution Index \\
\hline 1 & Muara Kamal & Exceeds & Heavy \\
\hline 2 & Cengkareng Drain & Exceeds & Heavy \\
\hline 3 & Muara Karang & Exceeds & Heavy \\
\hline 4 & Muara Angke & Exceeds & Heavy \\
\hline 5 & Gedung Pompa Pluit & Exceeds & Heavy \\
\hline 6 & Ancol & Exceeds & Medium \\
\hline 7 & Sunter & Exceeds & Light \\
\hline 8 & Muara BKT & Exceeds & Heavy \\
\hline 9 & Cilincing & Exceeds & Light \\
\hline 10 & Marunda & Exceeds & Heavy \\
\hline 11 & Muara Gembong & & \\
\hline
\end{tabular}

Source: Environmental Agency, 2016

\subsection{Jakarta Bay reclamation in political ecology approach}

Political ecology is an environmental science-based approach, which emphasizes human interaction with nature. Through a political ecology approach, this research looks at how interactions among stakeholders in the Jakarta Bay reclamation policy. This interaction in the reclamation of the Jakarta Bay resulted in differences in authority and different attitudes and interests that resulted in a conflict. In Political ecology the imbalance of authority and interest between actors over resources makes the existence of conflict. It is also a source of conflict in the Jakarta Bay reclamation policy. Overlapping authority regulations and the interests of different stakeholders have led to unclear policies of the Jakarta Bay reclamation to date.

In addition, political ecology also emphasizes the influence of actors in decision making. In the policy of Jakarta Bay reclamation, the interests of actors who play a strong role in an institution both the central government and the provincial government influence the attitudes and policies taken by the institution. This leads to more complex conflicts and the more important elements of environmental policy, the principle of sustainability. Pollution that occurred in Jakarta Bay requires an action. However, the current Jakarta Bay reclamation policy does not prioritize the principle of sustainability. This protracted conflict ultimately not only makes financial losses such as total value of estimated losses arising from the activities of Jakarta Bay reclamation perceived by fishermen and cultivators is Rp. 207.153.292.610, - / year [23], but also adds to the deterioration of the environment in the Jakarta Bay due to the omission of reclaimed lands [24]. 
Political ecology in the paradigm of an environmental management policy should prioritize a justice-based policy. A public policy on the environment must accommodate three interests, namely social, economic and environmental [25]. It can be done by community participating on decision making, and open data publicly. So, public can knows and participate to control the policy. The reclamation of the Bay of Jakarta has failed to become a public policy that can accommodate social, economic and environmental interests because of the dominance of one interest over other interests. This policy will continue to be a conflict between government institutions until there is awareness to equate knowledge and balance authority for the common good, ie sustainable environmental management for both people and the environment itself.

\section{Conclusion}

This study concludes that the Jakarta Bay reclamation policy creates a conflict between the central and provincial governments. This is due to the overlapping regulation of Jakarta Bay reclamation authority as well as differences in attitude and interests among stakeholders. In the approach of political ecology, the Jakarta Bay reclamation policy has failed to accommodate the three interests, are social, economic and environmental interests. The conflicts that occur also cause an omission that not only harms the economy but worsens the social and economic impact.

\section{Acknowledgements}

This research is funded by the Grant of Indexed International Publication for Final Project of Students/Publikasi Terindeks Internasional Untuk Tugas Akhir Mahasiswa (PITTA) Universitas Indonesia 2018 with contract number 2579/UN.R3.1/HKP.05.00/2018

\section{References}

1. H.S. Alikodra. The impacts of land reclamation of Jakarta Bay on mangrove ecosystem. Media Konservasi 5, 1 (1996)

2. R. Puspasari, S.T. Hartati, R.F. Anggawangsa. Analisis dampak reklamasi terhadap lingkungan dan perikanan di Teluk Jakarta. Jurnal Kebijakan Perikanan Indonesia 9, 2 (2017)

3. S. Fisher. Working with conflict: skills and strategies for action (Zed books, 2000)

4. S.P. Robbins. "Conflict management" and "conflict resolution" are not synonymous Terms. California Management Review 21, 2 (1978)

5. F. Stewart. Horizontal inequalities and conflict: Understanding group violence in multiethnic societies (Springer, 2016)

6. Arsyad, A. Coastal reclamation projects in Indonesia: the weaknesses which lead to severe socio-environmental impacts. Proceedings International Conference on Environmental Research and Technology. Universiti Sains Malaysia. (2008)

7. B. Mitchell, D.H. Rahmi, B. Setiawan. Resource and environmental management (Gadjah Mada University Press, 2003)

8. A.S. Cheng, L.E. Kruger, S.E. Daniels. "Place" as an integrating concept in natural resource politics: propositions for a social science research agenda. Society \& Natural Resources 16, 2 (2003) 
9. L. Talaue-McManus, A.C. Yambao, S.G. Salmo III, P.M. Alino. Cultivating Peace: Conflict and Collaboration in Natural Resources Management (International Development Research Centre, Canada, 1999)

10. V. Weitzner, M.F. Borrás. Cultivating Peace: Conflict and Collaboration in Natural Resources Management (International Development Research Centre, Canada, 1999)

11. J.F. McCarthy. Changing to gray: decentralization and the emergence of volatile sociolegal configurations in Central Kalimantan, Indonesia. World Development 32, 7 (2004)

12. D. Dirhamsyah. Indonesian legislative framework for coastal resources management: a critical review and recommendation. Ocean \& Coastal Management 49, 1-2 (2006)

13. A. Kustanti, B. Nugroho, C. Kusmana, D. Darusman, D. Nurrochmat, M. Krott, C. Schusser. Actor, interest and conflict in sustainable mangrove forest management-a case from Indonesia. International Journal of Marine Science 4, 16 (2014)

14. M.F. Giordano, M.A. Giordano, A.T. Wolf. International resource conflict and mitigation. Journal of Peace Research 42, 1 (2005)

15. T.F. Homer-Dixon. Environmental scarcities and violent conflict: evidence from cases. International Security 19, 1 (1994)

16. J.A. Douglas. What's political ecology got to do with tourism?. Tourism Geographies 16, 1 (2014)

17. J. Martinez-Alier. The Environmentalism of the poor: a study of ecological conflicts and valuation (Edward Elgar Publishing, 2002)

18. C.A. Kull, X.A. de Sartre, M. Castro-Larranaga. The political ecology of ecosystem services. Geoforum 61, (2015)

19. Z. Arifin. Politik ekologi: ramah lingkungan sebagai pembenaran. Jurnal Ilmu Sosial Mamangan 1, 1 (2012)

20. H. Tarigan. transformasi pertanian dan krisis air di bali dalam perspektif ekologi politik. Forum Penelitian Agro Ekonomi 34, 2 (2016)

21. W.R. Jati. Manajemen tata kelola sumber daya alam berbasis paradigma ekologi politik. POLITIKA: Jurnal Ilmu Politik 3, 2 (2012)

22. E. Colven. Understanding the allure of big infrastructure: Jakarta's great garuda sea wall project. Water Alternatives 10, 2 (2017)

23. A. Ramadhan, M. Firdaus, R.A. Wijaya, I. Muliawan. Estimasi kerugian nelayan dan pembudidaya ikan akibat reklamasi di Teluk Jakarta (Economic loss of fisher and fish farmer due to reclamation of Jakarta Bay). Jurnal Sosial Ekonomi Kelautan dan Perikanan 11, 1 (2016)

24. R. Puspasari, S.T. Hartati, R.F. Anggawangsa. Analisis dampak reklamasi terhadap lingkungan dan perikanan di Teluk Jakarta (Analysis of reclamation impacts on environment and fisheries in Jakarta Bay). Jurnal Kebijakan Perikanan Indonesia 9, 2 (2018)

25. A. Brotosusilo, D. Utari, A.A. Satria. Sustainability of water resources in the upstream watershed-based community engagement and multistakeholder Cooperation. IOP Conference Series: Earth and Environmental Science 30 012018, (2016) 